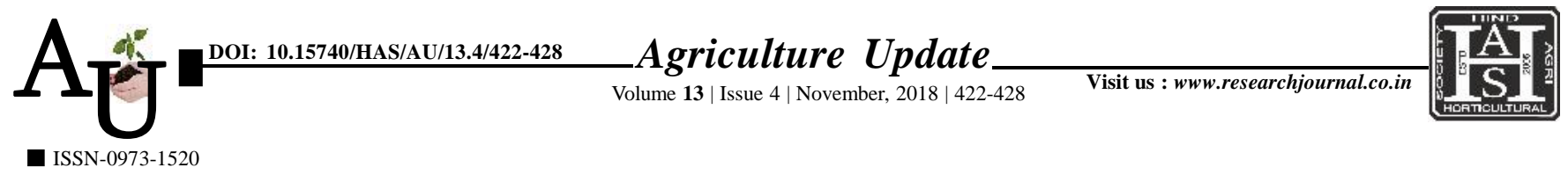

\title{
Research Article: Trends in fertilizer consumption in Maharashtra
}

\author{
P.M. Dahiwade, A.V. Gavali and A.R. Kulkarni
}

Article Chronicle: Received :

03.09.2018;

Revised :

25.09.2018;

Accepted :

10.10 .2018

KEY WoRds:

Fertilizer, Fertilizer

consumption,

Compound growth

rates
Author for correspondence :

\section{A.R. Kulkarni}

Department of Agricultural Economics, Mahatma Phule Krishi Vidyapeeth, Rahuri, Ahmednagar (M.S.) India Email: akhileshkulkarni 412@ gmail.com

See end of the article for authors' affiliations
SUMMARY : The regionwise compound growth rates were estimated for the time periods i.e. pre-WTO period (1960-61 to 1994-95), post-WTO period (1995-96 to 2012-13) and overall period (1960-61 to 201213). During the pre-WTO period the rates of compound growth in consumption of N, P and $\mathrm{K}$ at the overall level of Maharashtra were 6.06, 7.11 and 5.87 per cent per annum, respectively. The highest consumption of nitrogenous fertilizers was observed in Marathwada region $(10.38 \%)$ while highest consumption of phosphatic $(10.38 \%)$ and potassic $(9.92 \%)$ fertilizers were observed in western Maharashtra. During post-WTO period the consumption of nitrogenous, phosphatic and potassic fertilizers was lowest in Konkan region with the rate of growth of 0.99 per cent, 1.67 per cent and 2.02 per cent per annum, respectively. For the overall period (1960-61 to 2012-13), the consumption pattern of total fertilizers exhibits variation among all the regions in Maharashtra. The annual compound growth rates in phosphorus and nitrogenous consumption were substantially higher during pre-WTO period as compared to overall period and post-WTO period in Maharashtra State. Wide variations in NPK consumption in various regions was observed may due to variations in soil type, nature of cropping pattern, availability of irrigation, rainfed nature of crops and varied stages of agro-economic development.

How to cite this article : Dahiwade, P.M., Gavali, A.V. and Kulkarni, A.R. (2018). Trends in fertilizer consumption in Maharashtra. Agric. Update, 13(4): 422-428; DOI : 10.15740/HAS/AU/13.4/422-428. Copyright@ 2018: Hind Agri-Horticultural Society. 